\title{
Ethnic Factor in State Power in Kazakhstan
}

\section{Maral Bakhytzhanovna Zhanarstanova}

L.N. Gumilyov Eurasian National University, Department of Journalism and Political Science The Republic of Kazakhstan, Astana, 010008, Yanushkevich Street, 6

\section{Elena Leonidovna Nechayeva}

L.N. Gumilyov Eurasian National University, Department of Journalism and Political Science The Republic of Kazakhstan, Astana, 010008, Yanushkevich Street, 6

\section{Doi:10.5901/mjss.2015.v6n5s2p20}

\begin{abstract}
Kazakhs constitute the majority of the population (over 63\%) in Kazakhstan and their predominance in all spheres is understandable. However, there is a disparity in the percentage of Kazakhs in government and in the population of the republic. The case analyzed in the article is ethnic factor in state power in Kazakhstan. The argument of the article is that such disproportion between Kazakhs and other ethnic groups is rather the result of imperfection of personnel policy, impact of clan, tribal and family ties to personnel management, and language barriers in employment, than the result of discriminatory policy of the state.
\end{abstract}

Keywords: Kazakhization, kinship, ethnicity, multiethnic state, Russians in Kazakhstan, discrimination

\section{Introduction}

The end of XX century for Kazakhstan marked the emergence of a new political reality resulted from the collapse of communism and the subsequent transition to democracy. The collapse of the Soviet Union raised the national issue in new independent states, namely, the growth of ethnic identity feelings, the revival of national culture, language and customs of titular nations were common for all post-Soviet states. After 25 years of sovereignty Kazakhstan become a full-fledged member of the world community. The republic is a home for more than 100 ethnic groups and is proud of its own model of interethnic harmony, which is often perceived as a sole achievement of circumspect policy of the President Nazarbayev. Nevertheless, there are still issues in ethnic sphere that need improvement. Thus, for instance, as reported UN expert on minority issues in Kazakhstan

Members of smaller minority communities consider their opportunities for political participation to be extremely limited. Uighur community members noted that, even in regions in which they form the majority, they are rarely appointed to hold significant local government positions and are generally underrepresented in the public sector, especially in law enforcement bodies (United Nations, 2010, p.8).

Political leadership was afraid of the emergence of ethnic conflicts in Kazakhstan, as it happened in other postSoviet states. Nevertheless, all the way since 1991 Kazakhstan was able to safeguard political and ethnic stability in the country without any worth mentioning interethnic conflicts. At the same time, political representation of different ethnic groups in Kazakhstan's public policy in this direction has been targeted by many scholars.

The methodological base is represented by a mixture of different approaches of analysis, such as historical, institutional, structural and functional and others. Application of institutional approach to the analysis of the current situation in Kazakhstan's public policy allows us to study the actual relationship between legal principles, such as, for example, freedom, the supremacy of human rights, equality, etc.

The article is based on the case study, which helps to fully analyze situation in one particular country Kazakhstan. The topicality of the research article is determined by 1) the growing influence of ethnicity and ethnic identity that differentiate people all over the world; 2) high potential for ethnic conflict in any heterogeneous society, where Kazakhstan is not an exception; 3) lasting talks about kazakhization and, as a consequence, some political discrimination of other ethnic groups; 4) formation of a new personnel policy of Kazakhstan, which should be based on the meritocratic approach.

The article investigates ethnic aspect of public policy in multiethnic Kazakhstan, more precisely the phenomenon of 
titular nation's domination in civil services of the republic.

The article emphasizes that the ethnic aspect is of little consideration in the personnel policy of Kazakhstan. However, the reason lies not in politics of monopolizing power by Kazakhs, but due to other factors, such as informal ties, historical background and language issues.

\section{2. "Cadres Decide Everything"}

Efficiency of public bodies in many ways depends on personnel policy. Skills of civil servants are of paramount importance for the political system of any country.

Let's look at some civil servants who meant to improve functioning of the political system, but, however, didn't cope with the task.

Over the past couple of years Kazakhstan have seen a number of major corruption scandals associated with the names of prominent officials. Thus, several civil servants of the national and regional levels have been accused of corruption. Among them: 1) ministers and vice-ministers; 2) former mayors (akims) and 3) other civil servants (Note 1). It is quite interesting that all the officials accused of corruption are representatives of the titular nation, while they were not intentionally selected on national basis, as evidenced by the ratings of the largest corruption scandals in Kazakhstan (Bocharova, 2014; Ashilova, 2013). Though some officials were released from the court or conditionally sentenced, their professional ethics and work for the benefit of the state are in doubt. The question is whether it is an evidence of lack of professionalism of Kazakhs or the reason lies in their high percentage in power and as a consequence of more cases? Is it possible to conclude that other ethnic groups cope better with their responsibilities and less corrupt than Kazakhs? There are no clear answers for the questions and should be addressed in future researches using empirical analysis methods. However, it is possible to conclude with confidence that personnel policy and selection criteria need changes.

Among other things, the critique of Kazakhstan's public service often acquires ethnic coloring. Non-titular ethnic groups in the Republic of Kazakhstan note low level of their representation in the government. It is true in some aspects, as more than $80 \%$ of civil servants are Kazakhs, while their percent in the total population of the country is lower (63\%).

There is also an opinion that legislative body "should be in miniature an exact portrait of the people at large" (Adams, 2003, p.86), while being opposed by others (Melissa Williams, Iris Young, Jane Mansbridge, Will Kymlicka), noting that "this would lead to an unworkable proliferation of group representation and undermine the process of representative government." (Bird, 2003, p.65).

To analyze the political representation of ethnic groups in government it is accepted to use coefficient of Prazauskas (CPr) which shows the ratio of ethnic groups in the ethnic composition of the country to their share in the government. The coefficient is calculated by dividing the share of a particular ethnic group in relevant authorities to this ethnic group share in the proportion of the population (Note 2). According to Coefficient of Prazauskas, Kazakhs are overrepresented in state power ( $\mathrm{CPr}=1.33$ in lower Chamber of Parliament), while others are underrepresented (for Russians $\mathrm{CPr}=0,58$; for Germans $\mathrm{CPr}=1,26$ ) (Wierzbicki \& Mider, 2008, p.392). What are the reasons of such overrepresentation of some groups and underrepresentation of others?

There are two extreme standpoints on the issue. The first one is represented by radical national - patriots in Kazakhstan, according to which "there is only one people and one nation in Kazakhstan - the Kazakhs, while all the rest are representatives of foreign Diasporas" (Atabek, 2004), and only Kazakhs should govern the state. The second one is represented by Russian (Slavic) nationalists, who interpret 'kazakhization' of the political power as a form of discrimination, because of which there is no room for non Kazakhs in the government (Note 3). We are far from taking the sides, as the purpose of the article is scientific study of the issue, analysis of various theories and understanding the causes of the situation. In order not to make unreasonable statements, a number of issues must be considered, the first of which is the legal framework in this area.

\section{Legal Framework}

Ethnic sphere in Kazakhstan is regulated by the Constitution of the country, the Law "On languages", the Law "On elections", the Law "On the Assembly of People of Kazakhstan", and other. Normative control of the personnel sphere is complemented by the Labour Code, Law "On civil service", Code of honor of civil servants, decree of the President of the Republic of Kazakhstan "On civil service personnel reserve".

The constitution of Kazakhstan proclaims the principle of no discrimination "for reasons of origin, social, property status, occupation, sex, race, nationality, language, attitude towards religion, convictions, place of residence or any other circumstances" (Art. 14, p.2). It also states that "Citizens of the Republic shall have the equal right to serve in a public 
office. The requirements for candidates for public offices shall be conditioned only by the character of the office duties and shall be established by law" (Art. 33, p.4). Similar provision is prescribed in the Article 12, p. 4 of the Law "On Civil Service" in the Republic of Kazakhstan, according to which it is not permitted to impose discrimination to the civil service on grounds of origin, social, official or property status, sex, race, nationality, language, religion, beliefs, place of residence or any other circumstances (The Law of the RK"On Civil Service").

Concerning the representation of non-titular ethnic groups in power, the Constitution prescribes that "Nine deputies of Majilis shall be elected by Assembly of the people of Kazakhstan" (Art.51, p.1) (Note 4). As a result in parliamentary elections in 2012, 9 deputies of the Majilis elected by the Assembly were representatives of nine different ethnic groups: Aliyev Zh.- Kazakh, Ahmad M.A. - Uighur, Cappel E.Y. - German, Kim R.W. - Korean, Murad A.S. - Chechen, Nesterov N.D. - Russian, Sayapova Z.A. - Tatar, Y. Timoshenko - Ukrainian, and Khalmuradov R.S. - Uzbek.

However, their appointment rather than election leads to the fact that they are not responsible personally to their ethnic group, so do not depend on their support and may not reflect their interests. This in turn, call in question the effectiveness of this type of representation in terms of ethnicity.

Nevertheless, it is possible to suggest that the legal (on paper) basis for participation of ethnic groups in public sphere is quite justifiable. However, de facto Russians and other ethnic groups are represented in the civil services insufficiently. According to W.Kymlicka their demands for equal representation should be seen as a response for state's pressure and state nation-building (Kymlicka, 2001, p.1).

\section{Nation-building in Kazakhstan}

Kazakhstan was one of the most Russified state in post-Soviet area, where in the early period Kazakhs constituted a minority in their 'own' country. The situation started to change after gaining the independence. The growth of Kazakhs in comparison to other ethnic groups and especially Russians could be explained by several reasons: 1) natural demographic factor, namely high birth rate among Kazakhs. According to official report of Statistical Agency of RK, natural increase among Kazakhs in 2012 was 219677 people, while among Russians and Ukrainians the decline was seen (-5786 and - 4676 respectively) (Committee on Statistics, 2013); 2) return of Kazakhs from neighboring countries to their homeland. Thus, for instance, balance of migration of Kazakhs in 2009-2013 period was 115147 people, while the number of Russians for the same period decreased by 82192 people (Committee on Statistics, 2009-2013); 3) mass outflow of Slavs from the Republic of Kazakhstan - 1.5 million Russians left Kazakhstan between 1992 and 2000 (Olcott, 2005, p.60).

It is interesting that at the beginning of independence, according to Kolsto's research, $63 \%$ of Russians were ready to stay in the republic and $49 \%$ of respondents noted that a mass migration of Russians out of Kazakhstan are not very likely (Kolstø, 1993, p.202).

The ethnic landscape changed because of the "nationalizing policy" (Brubaker) of the state. The process of nationbuilding was inherent to most post-Soviet states. However, the revival of ethnic identity began long before gaining independence by these countries. Soviet policy aimed to unite all people and make them equal in rights, and still, Soviet internationalism had a "Russian face".

During the Soviet Union the Kazakh identity almost disappeared. That is why, the revival of Kazakh language, culture and traditions is seen by Kazakh authorities as a 'celebration of justice'. This falls under R. Brubaker's motifs of nationalizing discourse: "the distinction between core or titular nationality and others; the claim to titular primacy; the diagnosis of titular weakness; the call for remedial state action; and the justification in terms of compensation or redress" (Brubaker, 2011, p.1788). These motifs could be explained by the fact that among all post-Soviet countries Kazakhstan was the most russified one, consequences of which echoes even today. The dominance of Kazakhs should be considered not only from the standpoint of public policy. Though, you cannot deny the influence of it. After gaining independence Kazakhstan had a high potential for interethnic conflict, as the majority of the population were Slavs. There are examples (Georgia, Azerbaijan, Ukraine and others) in world history, when the compact settlement of ethnic groups in the state can cause a wave of separatism. That risk was also peculiar to Kazakhstan, which is why a lot of measures have been taken in order to decrease or even exclude the possibility of interethnic conflict. First of all, "inviolability and inalienability of territory" was constitutionally prescribed in Kazakhstan (Art.2 p2). Article 91 p.1 of the Constitution of the Republic of Kazakhstan also states that "territorial integrity of the Republic, the forms of government may not be changed".

Besides the legal securing other measures has been taken to indemnify inter-ethnic relations and "Russian issue": attraction of repatriates (Oralmans) and their resettlement in the regions with the dominance of the Slavs, move of the capital from Almaty to Astana for the control of the northern regions, delicate language policy, the creation of the 
Assembly of People of Kazakhstan and others. All the measures, undoubtedly, affect personnel policy and resulted in the domination of Kazakhs even in regions with a large percent of other ethnic groups, such as North and East Kazakhstan. However, it is not the only, and, perhaps, not the main reason of Kazakhization of public authorities, which are strongly affected by informal ties.

\section{Informal Channels of Personnel Management}

Despite the fact that it is not accepted in the political and scientific circles of Kazakhstan to talk openly about tribalism and nepotism in power, the brief investigation of the phenomenon is considered to be important for understanding the current situation in Kazakhstan.

The article argues that Kazakhs domination in civil services is the result of informal ties and not of the discriminatory policy of the state. In the article the informal relations refers to the kin, clan and tribal ties. It is stated that ethnicity doesn't play crucial role in personnel policy of Kazakhstan, rather these informal factors.

Kazakhs' mentality is very different from that of Slavic population, where family ties, kinship are illustrative of the first ones, and individuation of the second.

There is even a joke that characterizes Kazakh mentality: "Kazakh resume is the shortest in the world: I'm from Sake" (Note 5), meaning that recommendations from "Sake" are more than enough for any position. Unfortunately, this is the real case in Kazakhstan's reality.

As E.Schatz noted in his research Modern Clan Politics, even if some interviewees denied ever using kin connections, de facto they did so. This is also can be seen as Kazakhs mentality, to which "mutual assistance among kin" is peculiar, and which "distinguishes Kazakhs from other ethnic groups, especially Russians" (Schatz, 2013, p.63).

This statement is supported by a study conducted by opposition magazine "Freedom of speech" (Svoboda Slova). The study tried to find elite relatives of Kazakh state employees. Thus, for instance, son and daughter of the former Minister of Foreign Affairs (K. Saudabayev) worked as Consul in Australia and working counselor of the embassy in London respectively. One of his nephews has worked as Vice-Minister of Finance, and the other is the Director of Communication Assets Management of "Samruk-Kazyna". Deputies' children also joined the ranks of the state elite in Kazakhstan: Son of a senator Kuanysh Aytahanov worked as deputy mayor (akim) of South Kazakhstan region, the son of Senator Adil Akhmetov - Advisor to the President of 'Samruk-Kazyna Fund, the son of a senator Omirbek Baygeldi Deputy Head of Department of Financial Police in Astana. The eldest daughter of the vice-speaker of the Senate Mukhambet Copey worked as deputy mayor (akim) of Shymkent city, and his son - deputy regional akim. The study also shows examples of kin relationships among other deputies, in the Ministry of Foreign Affairs and in the national companies (The study of the genealogical tree, 2011).

In order to reduce the impact of kin relations in personnel policy, there is a provision in the Law of the Republic of Kazakhstan "On Civil Service", which states that civil servant cannot hold a position directly under the position held by his close relatives (parents, children, adoptive parents, adoptees, full and half brothers and sisters, grandparents, grandchildren) or spouse (wife), except as provided by law (Art.10, p.3).

Although kinship is not the main and only reason of state apparatus Kazakhization, it shows the difference in mentality between different ethnic groups and explains some of their actions.

Russian mentality or rather self-perception also affects the issue; the case in hand is language requirements for employment and reluctance of Russians to learn the state language.

\section{Kazakh Language: To Learn or Not to Learn?}

One of the main barriers for public service employment is Kazakh language. On the one hand, according to Law "On Civil Service" the only requirements for civil service's entry are citizenship of the Republic of Kazakhstan; be at least eighteen years old, unless otherwise laid down by the legislation of the Republic; to have the necessary education, level of training and meet the established eligibility requirements (Art. 13, p.1). Moreover, it is prescribed in the Law that any direct or indirect restrictions based on gender, race, ethnicity, language, social origin, property, place of residence, religion, beliefs, membership of voluntary organizations and any other circumstances are not allowed (Art. 12, p.4). On the other hand, there are rules of competition for the occupation of vacant administrative positions approved by the Chairman of the Agency on March 19, 2013 № 06-7 / 32. According to these rules, the competition involves citizens of the Republic of Kazakhstan with a certificate of passing tests, results of which are not below the threshold (Art. 6, p.2) (Order of the Chairman, 2013). Among others there is a test for knowledge of the state language, which in most cases is a screening factor, making it difficult for non-titular ethnic groups to enter the civil service. 
It is necessary to note that language issue is one of the most ambiguous and controversial in the republic. There are still $74 \%$ of Russians who think that two state languages should be in Kazakhstan (Vdovina, 2008). More importantly, more than $20 \%$ of Russians faced difficulties in employment for work because of lack of knowledge of state language (Kurganskaya, 2002). Nevertheless, despite the fact that Kazakh language assists in career promotion, the number of those knowing it among the Slavic population of Kazakhstan grew marginally.

On the one hand it may appear that the language barrier to employment is a form of discrimination against nontitular ethnic groups, which is not entirely true. Firstly, it should be noted that demands for knowing of Kazakh language have been implemented not from the first days of independence. Many years have passed before language requirements increased. Secondly, language barriers for civil service "discriminates" not only the non-titular population, but most of the Kazakhs themselves, since more than a half of Kazakhs do not know their native language. They are called as ShalaKazakhs. Zh. Zhakupov defines them as "Kazakhs who don't know Kazakh language and speak on Russian", and who distinguished by the rationalization of consciousness, cultural russification, higher standards of consumption and individualism (Zhakupov, 2009, p.10). They are closer to Russians than to "real" (nagyz) Kazakhs. Considering the former, there is an opinion among scholars that they still have imperial ambitions which leads to Russians' reluctance to fully integrate in new republics. The privileged position of Russians during the Soviet Union influenced on their position in successor states. Thus, for instance, R. Brubaker notes that Russians "tended to think of the entire Union rather than only the Russian Republic as 'their' national territory" (Brubaker, 1994, p.68). Becoming a national minority in new nationalizing states made them "external" nation (Brubaker), they even "had developed an identity of their own [...] without undergoing any kind of assimilation." (Kolstø, 2011, p.153).

D. Laitin in his Identity in Formation: The Russian-speaking Populations in the Near Abroad wonders if Russians can culturally and linguistically integrate in four post-Soviet states - Kazakhstan, Estonia, Latvia, Ukraine. In case of Kazakhstan the answer is "no" due to big difference between two main ethnic groups. That is why "Russian-speaking population will likely consolidate as an energetic, well-educated, but politically marginalized counterhegemony." (Laitin, 1998, p.360). In Estonia and Latvia the process of assimilation was more successful because of high standards of living in these states and attractiveness of the Baltic culture to Russians.

Does it mean that Russian-speakers in Kazakhstan deliberately do not learn the state language because it is not beneficial for them? Is the reason in non prestigious status of Kazakh language? There are no clear answers for these questions and we can only guess and make assumptions. Clearly this is another perspective for further study.

Considering the question at the title of the section "Kazakh language: to learn or not to learn?" the answer is "to learn", as long as language issues in Kazakhstan matter today and will not lose its significance in near future both for Russians and Shala-Kazakhs.

\section{Conclusion}

The total domination of core nation in the public sphere of Kazakhstan is undeniable. It is also generally accepted that other ethnic groups are underrepresented in the political life of the state. The research allows us to conclude that personnel policy does not consider ethnic aspect sufficiently, and there is still room for improvement of personnel policy of the republic. Kazakhization of civil service should not be analyzed only from the standpoint of nation-building policy, but also taking into account other factors, such as informal ties of Kazakhs, language barrier and unwillingness of Russianspeakers to cross it.

Though there is a representation of ethnic groups in Parliament through the Assembly of People, it is not enough, especially taking into account that these nine deputies are not elected by their ethnic groups. On the other hand, ethnic identity of deputies, officials and civil servants of Kazakhstan should not determine their status, career development or support among the population. Thus, for instance, disputes over nationality of the Prime Minister Karim Massimov (whether he is Uighur or Kazakh) must not overlap his professional qualities and adequacy for the job.

Next, we must recognize that nepotism and kinship are typical for Kazakhs. The appointment of people on the recommendation of "Sake", by a phone call, or by family-kin relationships lead to unprofessionalism of state apparatus. The issue needs to be addressed at the very high state level. Even if there is the rhetoric of politicians in Kazakhstan regarding meritocratic formation of state apparatus, starting from the highest ranks, the reality shows that informal channels of appointment prevail. So far all statements of politicians remain only in words, whereas we need more effective normative and practical measures, which will eliminate the influence of family ties in personnel policy. It is apparent that it is impossible completely eradicate tribalism, at least in the short term, however, additional control channels of the professional qualities of candidates are needed.

In terms of language it is necessary to create real economic motivation and rewards not only for Russians and 
other ethnic groups but also for Russian-speaking Kazakhs. These measures will help to take into account ethnic dimension of the personnel policy of Kazakhstan. But there are still questions to answer: Will the change in the ethnic composition of the authorities affect quality of their work? What will change with the number of members of other ethnic groups in the state apparatus? Will it benefit the country or cause new challenges and threats to internal security? Answers to them, hopefully, will be given in future studies.

\section{Notes}

1. Akhmetov S. (Prime Minister), Doskaliyev Zh. (Minister of Health), Burkitbayev S. (Minister of Transport and Communication), Umiryamov M. (vice minister of Agriculture), Shayakhmetov S. (vice minister of Education), Kuterbekov D. (vice minister of Transport and Communication); Abdishev B. (Karaganda region), Smagulov M. (Karaganda region), Aryn E. (Pavlodar region), Ryskaliev B. (Atyrau region); Asenov A. (head of the Kazakh military armaments' department), Meshimbayeva A. (head of Kazakhstan's Statistics Agency), Ospanov M. (head of Natural Monopolies Regulation Agency), Dzhulamanov N (the director of Border Service).

2. When CPr is equal to "1", it means that the ethnos is normally represented in the organs of government and administration. $\mathrm{CPr}>1$ means overrepresentation of the ethnic group in government authority, $\mathrm{CPr}<1$ shows that the ethnic group is underrepresented in state power.

3. See articles on the website www.russianskz.info

4. Assembly of People of Kazakhstan was established by the President in 1995 as an advisory body in matters of ethnicity. In 2007 the Constitution had been amended, by virtue of which, the Assembly received the constitutional status and the ability to represent ethnic groups in Parliament.

5. Sake illustrates here powerful and often rich man (named, for example, Serik).

\section{References}

Adams, J. (2003). The Political Writings of John Adams: Representative Selections. Hackett Publishing.

Ashilova, M. (2013). TOP-10: Samyye krupnyye korruptsionnyye skandaly 2013 goda! ("Top-10: The biggest corruption scandals of 2013!"). http://qaznews.kz/tor-10-samye-krupnye-korrupcionnye-skandaly-2013-goda.html

Atabek, A. (2004). "There is only one people and one nation in Kazakhstan" (In Russian). http://zonakz.net/articles/7484

Bird, K. (2003). "The Political Representation of Women and Ethnic Minorities in Established Democracies", presented for the Academy of Migration Studies in Denmark (AMID), Aalborg University http://www.hks.harvard.edu/fs/pnorris/Acrobat/stm103\%20articles/ Karen\%20Bird\%20amidpaper.pdf

Bocharova, M. (2014). "The unequal battle: 8 main corruption scandals in Kazakhstan" (In Russian). http://vlast.kz/article/neravnyj_boj_ 8_gromkih_korrupcionnyh_skandalov_v_kazahstane-8464.html

Brubaker, R. (1994) "Nationhood and the National Question in the Soviet Union and Post-Soviet Eurasia: An Institutionalist Account", Theory and Society, Vol. 23, Issue 1, pp. 47-78.

Brubaker, R. (2011, November). "Nationalizing states revisited: projects and processes of nationalization in post-Soviet states." Ethnic and Racial Studies, Vol. 34 No. 11, pp. 1785-1814.

Committee on Statistics. (2009-2013). Operational data (express information, bulletins). Migration of the population of the Republic of Kazakhstan.

Committee on Statistics. (2013) Demographic Yearbook of Kazakhstan. Data book (In Russian). Astana.

Kolstø, P. (1993, May). "The New Russian Diaspora: Minority Protection in the Soviet Successor States." Journal of Peace Research, Vol. 30, No. 2, pp. 197-217.

Kolstø, P. (2011). "Beyond Russia, becoming local: Trajectories of adaption to the fall of the Soviet Union among ethnic Russians in the former Soviet Republics", Journal of Eurasian Studies 2, pp. 153-163. doi:10.1016/j.euras.2011.03.006.

Kurganskaya, V.D. (2002). "Russian issue in Kazakhstan" (In Russian). http://www.kisi.kz/site.html?id=661

Kymlicka, W. (2001). Politics in the Vernacular: Nationalism, Multiculturalism, and Citizenship. Oxford University Press.

Laitin, D. (1998). Identity in Formation: The Russian-speaking Populations in the Near Abroad. Cornell University Press.

Olcott, M.B. (2005). Central Asia's Second Chance. Carnegie Endowment.

Order of the Chairman of Agency of the Republic of Kazakhstan for public service of March 19, 2013 No. 06-7/32. (In Russian). http://hrm-gov.kz/?page_id=353

Schatz, E. (2013). Modern Clan politics: The Power of "Blood" in Kazakhstan and Beyond. University of Washington Press.

The Constitution of the Republic of Kazakhstan of August 30, 1995 (with amendments of May, 2007). Accessed July 2011. http://www. akorda.kz/en/category/konstituciya

The Law of the Republic of Kazakhstan "On Civil Service" of July 23, 1999 № 453-I. (in Russian). http://online.zakon.kz/Document/? doc_id $=1013958$.

"The study of the genealogical tree of Kazakh elite continues. part V" (In Russian). Freedom of Speech, March 3, 2011 № 8 (303). 
http://www.zakon.kz/top_news/204272-issledovanie-genealogicheskogo-dreva.html.

United Nations. (2010). Report of the independent expert on minority issues. Mission to Kazakhstan. A/HRC/13/23/Add.1, http://www. osce.org/cio/68829

Vdovina, N. (2008). "Russian language in Kazakhstan" (In Russian). http://www.nomad.su/?a=14-200809170322.

Wierzbicki, A., Daniel Mider. (2008). Etnopolityka w Azji Centralnej: Między wspólnotą etniczną a obywatelską. (Ethnopolitics in Central Asia: Between ethnic community and citizens). Dom Wydawniczy Elipsa, 2008.www.russianskz.info

Zhakupov, Zh. (2009). Shala Kazakh - past, present, future (In Russian). Коммуникационное агентство Аскарбеков и Planklon Group. 